\title{
THE EFFECT OF INERTIA AND SATISFACTION ON CONSUMER LOYALTY IN ONLINE SHOPPING SITES
}

\author{
DOI: 10.17261/Pressacademia.2018.965 \\ JMML- V.5-ISS.3-2018(6)-p.214-225
}

\author{
Aysel Ercis ${ }^{1}$, Tugba Yildiz ${ }^{2}$, Fatma Gorgun Deveci ${ }^{3}$ \\ ${ }^{1}$ Atatürk University, Erzurum, Turkey. \\ ayselercis@atauni.edu.tr, ORCID: 0000-0002-9835-8574 \\ ${ }^{2}$ Bayburt University, Bayburt, Turkey. \\ tugbayildiz@bayburt.edu.tr, ORCID: 0000-0003-0260-0555 \\ ${ }^{3}$ Ataturk University, Erzurum, Turkey. \\ gorgun.deveci@atauni.edu.tr, ORCID: 0000-0001-8987-2478
}

Date Received: August 13, 2018

Date Accepted: September 26, 2018

To cite this document

Ercis, A., Yildiz, T., Deveci, F. G. (2018). The effect of inertia and satisfaction on consumer loyalty in online shopping sites. Journal of Management, Marketing and Logistics (JMML), V.5(3), p.214-225.

Permemant link to this document: http://doi.org/10.17261/Pressacademia.2018.965

Copyright: Published by PressAcademia and limited licenced re-use rights only.

\section{ABSTRACT}

Purpose- This study deals with the effect of the required qualifications of an online shopping sites on consumer inertia and customer satisfaction and loyalty.

Methodology- As a method of research, the convenience sampling method was preferred and face-to-face questionnaires were applied. Upon elimination of incomplete and incorrect questionnaires, 317 questionnaires were included in the evaluation.

Findings- According to the results of the study, the adaptation, transaction ease and engagement which are dimensions of a website's required qualifications are effective on consumer inertia. On another note, adaptation, interaction, commitment, transaction ease and engagement are dimension which have an impact on customer satisfaction. While alternative attraction has a moderator role in the relationship between consumer inertia and loyalty, positive word-of-mouth has not been proven to have a moderating effect in the relationship between customer satisfaction and loyalty.

Conclusion- This study reveals the factors affecting inertia and satisfaction in consumers and the moderator effects in making loyalty.

Keywords: Consumer inertia, alternative attraction, customer satisfaction, positive word-of-mouth, loyalty.

JEL Classification: M39, M30, L81

\section{INTRODUCTION}

Websites today are doubling the place and time independency of companies in their communication with the market. By ensuring market access for companies, these systems offering unlimited products and services, twenty four hours a day, unlike the limited product range and work hours offered by the conventional store system are making it much easier for consumers to shop anywhere in the world, at any time of the day (Razak, Ilias and Rahman, 2009: 42). With website use becoming more widespread, active engagement in online communities is increasing. For this reason, determining the factors which affect engagement and loyalty in online communities carries significance in terms of seizing the online market (Zhou and Amin, 2014). Becoming more price and quality sensitive in their quest for value, consumers today are noticing fewer differences between competing products and are therefore demonstrating less brand loyalty (Moore and Carpenter, 2006). Due to time pressure and extra expenses, consumers who dislike perusing through different stores are preferring online shopping a lot more. At this point, websites based on consumer needs are able to create satisfying shopping experiences and are able to carry their businesses towards their profit targets (Richard and Chandra, 2005). Hence, in terms of customer satisfaction and loyalty, the required qualifications of the website's online transactions is a significant component. 
Consumer inertia is when a consumer purchases the same brand due to habitual reasons or because it requires less effort (Solomon, 1994). In other words, consumers inertia is unconsciously loyal to product and service providers. They carry out repeated purchases without much thought. As the service quality perceived in an online environment demonstrates an increase, the customer is more satisfied and as a result of this satisfaction, their loyalty towards the website also increases (Cristobal, Flavián, and Guinaliu, 2007). Positive word-of-mouth is important for marketers. This is because positive wordof-mouth increases the degree of preference for products and services without the need for additional promotion or advertising costs (Lien and Cao, 2014: 106). Alternative attraction expresses the probability of receiving a better service from providers of alternative goods and service (Keaveney, 1995). As the number of alternative products and services increase, unsatisfied consumers will display an effort to change their current choices of brands (Jones, Mothersbaugh, and Beatty, 2000: 263). In this study, the effect of the required qualifications of an online shopping sites on consumer inertia and customer satisfaction has been examined. The purpose of this study is to determine whether inertia or satisfaction is the driving factor in loyalty towards websites. In other words, the prevalent questions are: "is it false loyalty?" or "real loyalty?" In that, even if the result is identical, the reasons may differ. Accordingly; strategies to be implemented will also differ. Also, the moderating effect of positive word-of-mouth and alternative attraction on formation of loyalty will also be examined.

\section{LITERATURE REVIEW}

\subsection{Required Qualifications of Web Sites}

Chen, Clifford and Wells (2002) recommend the following elements in effective website design to e-retailers; making users feel comfortable, creating sites that are fun to use, and creating sites that influence consumers to spend more time and to re-visit and to increase the potential to re-purchase. Anderson and Swaminathan (2011), on the other hand, have offered six factors which influence website's required qualifications or customer satisfaction. These are; adaptation, interaction, assortment, transaction ease and engagement. The study's required qualifications variables are based on the Anderson and Swaminathan (2011) study and detailed information in relation to the dimensions is presented below.

\subsubsection{Adaptation}

Adaptation can be defined as how an e-commerce company becomes acquainted with the customers and later adapts its products, services and online shopping experience to the customer. Companies that are able to adapt their websites in accordance with their customer-base have considerable advantages (Anderson and Swaminathan, 2011). Adaptations are necessary in order to ensure positive outcomes such as increasing the global awareness of a website, attracting international customers, creating a positive attitude towards the site, making online purchases easy to complete, and increasing satisfaction (Harrison-Walker, 2002: 15). Because this way, the customer will spend less time and effort to search for the product and service he or she wants (Anderson and Swaminathan, 2011).

\subsubsection{Interaction}

Interaction, is a concept that describes the opportunity of customers to contribute to the content of the website. In other words, interaction is trying to make it fun of online shopping. A website with interactive features allows companies to observe the visitors of a website. In this context, the opportunity to obtain feedback from shoppers emerges. Therefore, interactions provide advantages to both consumers and companies (Park and Park, 2009: 362; Roy Dholakia and Zhao, 2009: 833, Anderson and Swaminathan, 2011: 222). In their study conducted on automobiles, Raney, Arpan, Padhupati and Brill, (2003) have reported that websites provide consumers with the opportunity to interact through various tools.

\subsubsection{Commitment}

Although there are many definitions of commitment, The common point of definitions is that the future relationship can be sustained (Kim, Zhao and Yang, 2008: 5). Commitment describes the strong relationships built between the firm and the customer in online shopping. The concept of commitment involves the firm's ability to resolve issues in delivery, installation and repairs and the manner in which they respond to customer concerns and complaints (Anderson and Swaminathan, 2011: 223). In order to maintain long-term relationships between customers and businesses in the online environment, the commitment taken on by the website carries significance (Casalo, Flavián and Guinalíu, 2007). After a relationship is formed, the commitment, the service and product quality desired by the consumer are also dependent on the degree which a firm meets his or her needs (Dann and Dann, 2011: 242). In their study, Mousaveian, Ebrahimpour, Hasanzadeh, and Mousaveian, (2016) have reported that the rate of satisfaction towards electronic banking services are increased by the level of commitment demonstrated in the electronic environment. 


\subsubsection{Assortment}

Another component which motivates individuals to shop in general is the search for assortment (Noble, Griffith, and Adjei, 2006). Consumers are attracted to assortment, because the possibility of finding what they are looking for is much higher when they visit a store which offers a wide range of products. Retailers also give importance to assortment because customers value assortment (Hoch, Bradlow, Wansink, 1999). Product variety expresses an e-store's ability to offer a wide range of products and services. The development of choices in e-stores reduces the costs customers endure and are therefore increases satisfaction and loyalty (Anderson and Swaminathan, 2011; Szymanski and Hise, 2000). In a study conducted by Christodoulides and Michaelidou (2010) which focused on determining the primary motivations of electronic quality perception, satisfaction and loyalty, it was concluded that a search for assortment had a positive affect on satisfaction. That is, displaying an unlimited range of products via the internet creates a platform which allows to customize the product customers (Razak, llias and Rahman, 2009: 41). The search for hedonic and utilitarian benefits leads to customers evaluating certain features of online stores such as visual design, product variety, quality of knowledge and after-sales service. Moreover, the features of online stores have a positive effect on the intention to become customers again (Koo, Kim and Lee, 2008). There are three benefit in online shopping. They offer more diversity, better opportunities and convenience (Pechtl, 2003: 148).

\subsubsection{Transaction Ease}

For a customer to have a comfortable online shopping experience, it is important for relevant information to be accessible and for the transaction process to be simple. Transaction ease refers to the extent to which a customer feels that the website is user-friendly (Anderson and Swaminathan, 2011). During the e-shopping process, both consumers and firms communicate and coordinate by means of information exchange and information sharing via the internet (Shih and Chiang, 2004: 356). In the age of electronic marketing, major investments in technologies which will assist in reducing transaction costs are being implemented (Sheth and Sharma, 2005). This is due to the fact that the usability of a website is linked to the product-related information and the ease of carrying out transactions (Zhang, Fang, Wei, Ramsey, McCole and Chen, 2011). Difficulties experienced will have a negative effect on customers making purchases over the internet or on their thoughts concerning their future shopping (Taylor ve England, 2006: 77). The ease of online shopping affects consumer satisfaction and this also determines channel preferences (Devaraj, Fan and Kohli, 2002). Web site design is important in online shopping. Web site design is based on ease of use and customer benefit in the online shopping process (Lee and Lin, 2005).

\subsubsection{Engagement}

Online shopping sites take care that they present attractive lively interesting and exciting images, formats and contents. This way, firms try to develop websites which attract individuals both visually and mentally. In this sense, engagement is the general image or personality reflected onto customers with the e-store's effective use of texts, styles, graphics, colors, logos, slogans and themes (Anderson ve Swaminathan, 2011: 224). Firms view consumer engagement as a means of transforming short-term relationships into long-term, and cordial relationships (Sashi, 2012: 254). As customer engagement increases, their loyalty, satisfaction and trust also increase (Brodie, llic, Juric, and Hollebeek, 2013). Therefore, firms are not only focused on market shares or increasing demand, but also on customer relations and ensuring engagement (Dutot, 2013).

\subsection{Consumer Inertia}

The concept of inertia defines an individual's inactivity, their lazy approach towards any given situation, their monotony, passive approach; that is, a general tendency to not take action and remain inactive (Çankaya and Demirtaş, 2010). In cases of regular shopping, if the person is acting in a habitual manner, a state of inertia is in question. In other words, consumers who do not wish to take risks continue their previous shopping habits (Bozzo, 2002: 2-3). Again, it is an unconscious process by which consumers habitually buy the same brand (Huang and Yu, 1999: 525). If an individual's inertia is due to cost and time-related pressure, it will be effective for a long period (Pitta, Franzak and Fowler, 2006: 423). Zhao, Tian and Li, (2012: 138 ) describe the state of a consumer continuing to buy a brand unconsciously as a result of their previous use of these brands as inertia, and their abandoning of such behavior as a search for assortment. In their study, Liu, Wu and Hung (2007) have argued that even when alternatives are attractive, demonstrate reluctance towards changing a brand or firm if they have a high level of inertia. Solomon (2007) claims that, based on his or her previous consumption experiences, when a consumer becomes used to a certain product or service provider, inertia prevails. Contrary to consumers with a low level of inertia, those with a high level of inertia tend to continue their existing state (Lee ve Neale, 2012). According to studies available in literature, there are various reasons for consumers to shop in a state of inertia. The first is a consumer's desire to save time. Consumers who behave this way do not spend time to find a new website. In other words, they do not the compare products and services of different stores. The second is the consumer's familiarity with the product. This way, by continuing to shop from the same store, they take fewer risks. The third is that there is not much difference between these particular stores and their alternatives (Anderson and Srinivasan, 2003; Liu et al., 2007; Oliver, 1999; Solomon, 2007; Tsai 
and Huang, 2007; Kuo, Hu and Yang 2013). As the inertia levels of a customer increases, he or she demonstrates a tendency to buy a certain product for a number of times. This is because customers may feel uncomfortable from the time and investment required to make a different choice (Colgate and Lang, 2001; Yanamandram and White 2006). In their study, Cheng et al. (2011) report that consumption frequency has positive effect on inertia; and perceived price a negative effect. Yanamandram and White (2010) state that the cost of evaluating a new service provider and the high cost of obtaining information about them increase inertia. Lucia-Palacios, Pérez-López and Polo-Redondo, (2016) report that the satisfaction experienced in previous usage has a positive effect on inertia. The hypothesis indicated below has been developed in the light of the information presented above.

$H 1$ : The of required qualifications a website influence consumer inertia.

\subsection{Customer Satisfaction}

Customer satisfaction indicates how well an individual's expectations have been met (Bayraktar, Tatoglu, Turkyilmaz, Delen, and Zaim, 2012). In other words, customer satisfaction is the extent to which a consumer's expectations are met. Anderson and Swaminathan, (2011: 225) have state that customer satisfaction is "a self evaluation by a customer before and after a purchase to see whether a his or her expectations have been met or exceeded in terms of their pre and post-purchase experience." Customer satisfaction is the outcome of a comparison between expected. and perceived performance throughout the customer relationship process (Wangenheim, 2003).

In their study, Cristobal et al. (2007) argued that as the perceived quality of a website increases, the satisfaction will also increase. Kassim and Asiah Abdullah (2010) have identified a positive relationship between satisfaction and the website's design, how user-friendly it is, and the trust conveyed. Szymanski and Hise (2000) have also expressed that user friendliness, website design and financial reliability are important factors in evaluation of customers' e-satisfaction. In this respect, unless customers' expectations are met in an online environment, the chances of these individuals staying loyal or being satisfied are very low. Firms who do not ensure loyalty and satisfaction will not be able to be successful in the longterm and maintain their existence (Anderson and Swaminathan, 2011). In line with the information presented above, the following hypotheses have been developed.

$\mathrm{H} 2$ : The of required qualifications a website influence customer satisfaction.

\subsection{Alternative Attraction}

The attraction of alternatives express the way a customer perceives alternatives offered by competitors (Jones et al., 2000: 262). As the information offered during the online shopping process is considerably clear and effective, there is fierce competition between firms on this platform. As the number of alternatives increase, the inertia or satisfaction-based repeated purchasing tendencies may weaken in the online environment and customers may steer towards more attractive stores (Kuo et al., 2013: 173). In other words, the possibility of a satisfied customer staying loyal to a firm is high, and the possibility of them searching for a competing product or service is low (Anderson and Swaminathan, 2011: 225). According to Masood and Javaria (2016), it has been determined that the attractiveness of alternatives has a negative moderating effect between the trust in an online environment and repurchase intention. In their studies, Kuo et al (2013 have determined that alternative attraction has no moderating effect on the relationship of both consumer inertia and satisfaction with re-purchase behaviour. The following hypothesis has been developed in light of the information presented above:

H3: Alternative attraction has a moderating effect on the relationship between consumer inertia and consumer loyalty.

\subsection{Positive Word of Mouth}

Word of mouth communication is "the unofficial communication between consumers in relation to the ownership, usage or features of certain goods and services" (Westbrook, 1987: 261). Positive word of mouth is "when satisfied consumers relay positive comments to other individuals in relation to the service and service provider" (File and Prince, 1992: 25). Consumers in an online environment have two types of access to information concerning the product. The first of these is the advertisements of the seller. The other is the consumer comments based on the experiences and evaluations of those who have previously shopped. Also, electronic word-of-mouth (eWOM), also called online comments, suggestions and online views have gained importance with the emergence of new technology tools (Cantallops ve Salvi, 2014: 41). Positive messages received from a customer's trusted friend also increases the possibility of them developing a sense of loyalty towards the firm (Leisen ve Prosser, 2004). In their study, Maxham III and Netemeyer (2002) identified that word-of-mouth is effective on intention when it comes to solving issues experienced with the product. Leisen and Prosser (2004), determined that when customer satisfaction is in question, high prices of products do not have an effect on positive wordof-mouth communication. In their studies, Kuo et al. (2013) identified that positive word-of-mouth has a moderating role in 
the relationship between customer satisfaction and re-purchasing tendencies. The $\mathrm{H} 4$ hypothesis has been developed in the light of this information.

H4: Positive word of mouth has a moderating effect on the relationship between customer satisfaction and consumer loyalty.

\subsection{Consumer Loyalty}

It is crucial for firms in fierce competition in the online environment to understand the factors which will ensure loyalty in their customers. In this context, one of the factors which affect loyalty is the satisfaction of a consumer (Anderson and Srinivasan, 2003). In their study, Kim, Jin and Swinney (2009) report that the satisfaction felt in the electronic environment affects loyalty. Anderson ve Swaminathan, (2011) express that as the inertia levels of an individual increases, his or her tends to demonstrate a lot more loyalty. In another study conducted, Wu (2011) argues that inertia has a positive effect on the consumer's sense of loyalty. In another study conducted by Anderson and Srinivasan (2003: 125), e-loyalty is defined as "the customer's display of positive attitude towards the e-retailer as a result of his or her repeated purchasing." Customers may refrain from making the effort required in order to get used to a new seller or spending the extra time necessary to be acquainted with them (Yang and Peterson, 2012: 802). The following hypotheses have been developed in light of the information presented above:

H5: Consumer inertia influences consumer loyalty.

H6: Customer satisfaction influences consumer loyalty

\section{DATA AND METHODOLOGY}

\subsection{Purpose, Scope and Limits of the Study}

In this study, the effect of the dimensions of adaptation, interaction, commitment, assortment, transaction ease and engagement, which determine the required qualifications of the website, on consumer inertia and customer satisfaction were examined. The effects of consumer inertia and customer satisfaction on consumer loyalty were also discussed. Lastly, the moderating role of alternative attraction in the relationship between consumer inertia and consumer loyalty, and the moderating role of positive word-of-mouth variable in the relationship between customer satisfaction and consumer loyalty were examined. The population of this study consists of adult consumers over 18 years of age, who live in Erzurum. Since no particular product group has been the focus of this study, the results obtained from this study can not be generalized for product group and Turkey in general. Online shopping is a rapidly developing method that enables consumers to save space, time, and various costs compared to traditional shopping, and easily reach the desired product without being bound by time or place. In recent years, many consumers prefer online shopping. Consumer inertia is that consumers buy the same brand constantly because they gain time, become familiar with the product and do not see any difference between stores. For this reason, the original point of this research; in the context of consumer inertia, while all these conditions are present, it is to be investigated whether the consumer loyalty is a real loyalty or false loyalty. Another original point of this research; the moderating effect alternative attraction in the relationship between consumer inertia and loyalty and the moderating effect of loyalty and the positive word-of-mouth communication in the relationship between customer satisfaction and loyalty will be examined.

\subsection{Research Model}

Figure 1. Research Model

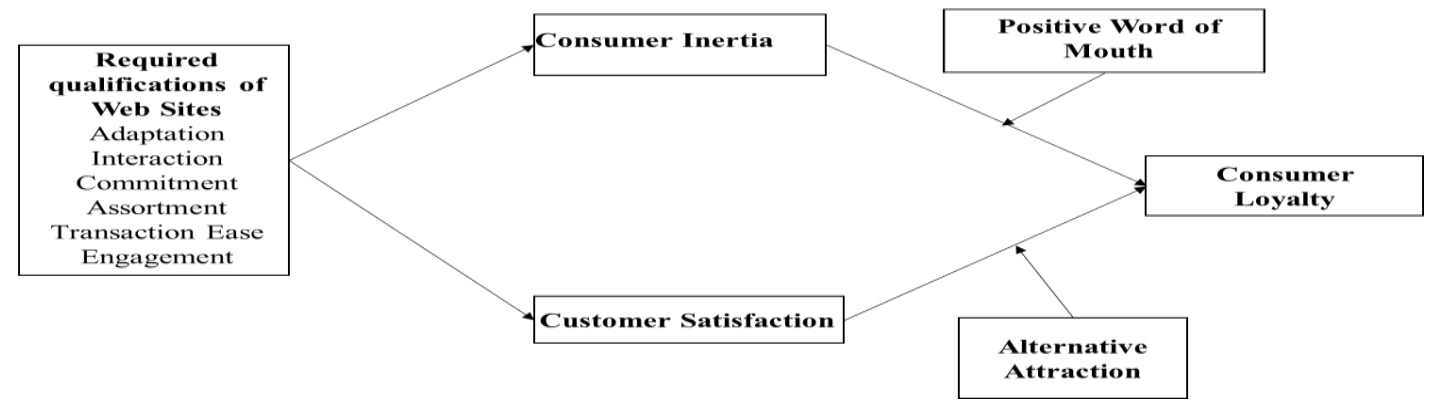

\subsection{Sample}

The population of this study consists of adult consumers (over 18 years of age) who live in Erzurum. As a method of research, the convenience sampling method was preferred and face-to-face questionnaires were applied. The 
questionnaire forms of only consumers who answered "Yes" to whether they do online shopping were taken into consideration. Upon elimination of incomplete and incorrect questionnaires, 317 questionnaires were included in the evaluation.

\subsection{Data Collection Method and Process}

The survey form was composed of 3 main sections. Questions contained in the first section were directed in order to determine the shopping web sites that consumers. In the second section, questions were asked in relation to the variables of the study: the required qualifications and sub-dimensions of the websites, consumer inertia, customer satisfaction, positive word-of-mouth, alternative attraction and consumer loyalty. Of the scales used to form the survey; the consistency between the sub-dimensions of the required qualifications of the website: adaptation, interaction, assortment, transaction ease, commitment, and engagement-related comments and consumer loyalty were obtained from the study conducted by Anderson and Swaminathan (2011). Comments related to consumer inertia were obtained from the studies conducted by Kuo et al. (2013) and Anderson and Srinivasan (2003); customer satisfaction, positive word-of-mouth and alternative attraction were adapted from Kuo et al (2013) and translated into Turkish. Questions in the last section were generated with the aim of determining the demographic features of respondents. A data analysis was carried out by SPSS 20.0 package statistics software. Descriptive statistics, multiple regression analysis and hierarchic regression analysis were utilized to analyze the data.

\section{FINDINGS AND DISCUSSIONS}

\subsection{Demographic Characteristics of Respondents}

The majority of respondents are 18-28 years of age (68.4\%), have university level education (67.2\%), an income of $1000 \mathrm{TL}$ or less (37.3), are generally composed of women (49.9\%), students (34.5) and single people (69.6\%). It is observed that respondents generally shop from hepsiburada.com (53.0\%), n11 (51.1\%), and Gittigidiyor (50.6\%).

\subsection{Regression Analysis Application}

With the aim of testing the research method, the reliability of the scales was analyzed prior to the regression analysis and all scales were found to be within reliability limits. Multiple regression and hierarchic regression analyses were utilized to test the research model. The multiple regression analysis was utilized to determine the variables in the study; the effect of website's required qualifications on consumer inertia and customer satisfaction, and again, the effect of consumer inertia and customer satisfaction variables on consumer loyalty. The results have been listed below

Table 1: Effect of Web Site's Required Qualifications on Consumer Inertia

\begin{tabular}{|l|l|l|l|l|l|}
\hline & $\mathrm{R}$ & $\mathrm{R}^{2}$ & Adjusted $\mathrm{R}^{2}$ & \multicolumn{2}{l|}{ Std. Error of the Estimate } \\
\cline { 2 - 6 } & 0,465 & 0,216 & 0,201 & 0,51288 & Sig. \\
\hline ANOVA values & Sum of Squares & $\mathrm{df}$ & Mean Squares & $\mathrm{F}$ & 0,000 \\
\hline Regression & 22,604 & 6 & 3,767 & 14,322 & \\
\hline Residual & 81,807 & 311 & 0,263 & & \\
\hline Total & 104,411 & 317 & & & \\
\hline
\end{tabular}

A show in the table 1, the dimensions which represent the required qualifications of the website explain $21.6 \%$ of the Consumer Inertia variable. The model is significant in terms of the ANOVA values.

Table 2: Beta Values Related to the Effect of Web Site's required Qualifications on Consumer Inertia

\begin{tabular}{|l|l|l|l|l|l|}
\hline & \multicolumn{2}{|l|}{ Unstandardized Coefficients } & Standardized Coefficients & \multirow{2}{*}{ t } & \multirow{2}{*}{ Sig. } \\
\cline { 2 - 6 } & $\mathrm{B}$ & Std. Error & $\mathrm{B}$ & $\mathbf{6 , 0 8 0}$ & $\mathbf{0 , 0 0 0}$ \\
\hline Adaptation & $\mathbf{0 , 3 5 5}$ & $\mathbf{0 , 0 5 8}$ & $\mathbf{0 , 3 4 7}$ & $-1,283$ & 0,200 \\
\hline Interaction & $-0,093$ & 0,072 & $-0,077$ & 0,163 & 0,871 \\
\hline Commitment & 0,010 & 0,063 & 0,010 & $-1,139$ & 0,256 \\
\hline Assortment & $-0,069$ & 0,061 & $-0,067$ & $\mathbf{2 , 3 9 1}$ & $\mathbf{0 , 0 1 7}$ \\
\hline Transaction ease & $\mathbf{0 , 1 9 1}$ & $\mathbf{0 , 0 8 0}$ & $\mathbf{0 , 1 5 5}$ & $\mathbf{2 , 6 1 7}$ & $\mathbf{0 , 0 0 9}$ \\
\hline Engagement & $\mathbf{0 , 2 0 8}$ & $\mathbf{0 , 0 8 0}$ & $\mathbf{0 , 1 5 5}$ &
\end{tabular}

According to the regression analysis results; while the dimensions of adaptation, transaction ease and engagement are effective on consumer inertia, the dimensions of interaction, commitment and assortment are not. For this reason, the $\mathrm{H} 1$ hypothesis has been partially accepted. 
Table 3: Effect of Web Site's Required Qualifications on Consumer Satisfaction

\begin{tabular}{|l|l|l|l|l|c|}
\hline & $R$ & $R^{2}$ & \multicolumn{2}{l|}{ Adjusted R } & \multicolumn{2}{l|}{ Std. Error of the Estimate } \\
\cline { 2 - 6 } & 0,668 & 0,447 & 0,436 & 0,50621 & Sig. \\
\hline ANOVA values & Sum of Squares & $\mathrm{df}$ & Mean Squares & $\mathrm{F}$ & 0,000 \\
\hline Regression & 64,320 & 6 & 10,720 & 41,834 & \\
\hline Residual & 79,695 & 311 & 0,256 & & \\
\hline Total & 144,015 & 317 & & & \\
\hline
\end{tabular}

As observed in Table 3, dimensions which present the required qualifications of the website explain $44.7 \%$ of the Customer satisfaction. The model is significant in terms of the ANOVA values.

Table 4: Beta Values Related to the Effect of Web Sites's Required Qualifications on Consumer Satisfaction

\begin{tabular}{|l|l|l|l|l|l|}
\hline & \multicolumn{2}{|l|}{ Unstandardized Coefficients } & Standardized Coefficients & \multirow{2}{*}{$\mathrm{t}$} & \multirow{2}{*}{ Sig. } \\
\cline { 2 - 6 } & $\mathrm{B}$ & Std. Error & $\mathrm{B}$ & $\mathbf{2 , 5 2 6}$ & $\mathbf{0 , 0 1 2}$ \\
\hline Adaptation & $\mathbf{0 , 1 4 6}$ & $\mathbf{0 , 0 5 8}$ & $\mathbf{0 , 1 2 1}$ & $\mathbf{2 , 4 6 7}$ & $\mathbf{0 , 0 1 4}$ \\
\hline Interaction & $\mathbf{0 , 1 7 6}$ & $\mathbf{0 , 0 7 1}$ & $\mathbf{0 , 1 2 4}$ & $\mathbf{2 , 7 8 7}$ & $\mathbf{0 , 0 0 6}$ \\
\hline Commitment & $\mathbf{0 , 1 7 5}$ & $\mathbf{0 , 0 6 3}$ & $\mathbf{0 , 1 4 1}$ & 0,403 & 0,687 \\
\hline Assortment & 0,024 & 0,060 & 0,020 & $\mathbf{3 , 4 0 1}$ & $\mathbf{0 , 0 0 1}$ \\
\hline Transaction ease & $\mathbf{0 , 2 6 8}$ & $\mathbf{0 , 0 7 9}$ & $\mathbf{0 , 1 8 5}$ & $\mathbf{6 , 9 1 7}$ & $\mathbf{0 , 0 0 0}$ \\
\hline Engagement & $\mathbf{0 , 5 4 3}$ & $\mathbf{0 , 0 7 9}$ & $\mathbf{0 , 3 4 4}$ & & \\
\hline
\end{tabular}

According to the regression analysis results; while the dimensions of convenience, interaction, transaction ease and engagement are effective on customer satisfaction, the dimension of assortment is not. For this reason, the $\mathrm{H} 2 \mathrm{hypothesis}$ has been partially accepted.

Table 5: Impact of Consumer Inertia and Customer Satisfaction on Loyalty

\begin{tabular}{|l|l|l|l|l|l|}
\hline \multirow{2}{*}{} & $\mathrm{R}$ & $\mathrm{R}^{2}$ & Adjusted $\mathrm{R}^{2}$ & \multicolumn{2}{l|}{ Std. Error of the Estimate } \\
\cline { 2 - 6 } & 0,612 & 0,374 & 0,370 & 0,47365 & \\
\hline ANOVA Values & Sum of Squares & $\mathrm{df}$ & Mean Squares & $\mathrm{F}$ & Sig. \\
\hline Regression & 42,256 & 2 & 21,128 & 94,177 & 0,000 \\
\hline Residual & 70,669 & 315 & 0,224 & & \\
\hline Total & 112,925 & 317 & & & \\
\hline
\end{tabular}

As presented in the table, consumer inertia and consumer satisfaction explain $37.4 \%$ of the loyalty variable. The model is significant in terms of the ANOVA values.

Table 6. Beta Values Related to the Effect of Consumer Inertia and Customer Satisfaction on Loyalty

\begin{tabular}{|l|l|l|l|l|l|}
\hline \multirow{2}{*}{} & \multicolumn{2}{|l|}{ Unstandardized Coefficients } & Standardized Coefficients & \multirow{2}{*}{ t } & \multirow{2}{*}{ Sig. } \\
\cline { 2 - 5 } & $\mathrm{B}$ & Std. Error & $\mathrm{B}$ & 4,227 & 0,000 \\
\hline Inertia & 0,207 & 0,049 & 0,199 & 10,966 & 0,000 \\
\hline Satisfaction & 0,458 & 0,042 & 0,517 & & \\
\hline
\end{tabular}

According to the regression analysis results; consumer inertia and customer satisfaction are effective on loyalty. The H5 and $\mathrm{H} 6$ hypotheses have been accepted in accordance with this result.

\section{Hierarchical Regression Analysis}

Following the multiple regression analysis, a hierarchical regression analysis was utilized to determine the moderating role of the attractiveness of alternatives variable in the research model in the relationship between consumer inertia and consumer loyalty, and the moderating role of the positive word-of-mouth variable in the relationship between consumer satisfaction and consumer loyalty. The Moderator Variable, in general terms, is a qualitative or quantitative variable which influences the direction and/or strength of the relationship between an independent or predictor variable with a dependent or criterion variable (Baron and Kenny, 1986). In other words, the moderator variable specifies how long and 
under what conditions an independent variable influences a dependent variable (Lindley and Walker, 1993; Kim, Kaye, and Wright, 2001).

Within the scope of the study, the aim was to examine whether the Alternative attraction variable has a moderator effect in the relationship between consumer inertia and consumer loyalty. In the table, the moderator effect of alternative attractive is presented.

Table 7: The Moderator Effect of Alternative Attractive

\begin{tabular}{|c|c|c|c|c|c|c|}
\hline Model & & B & $\begin{array}{l}\text { Std. } \\
\text { Error }\end{array}$ & B & $\mathbf{t}$ & Sig. \\
\hline Inertia & & 0,383 & 0,054 & 0,368 & 7,031 & 0,000 \\
\hline$R^{2}=0,135$ & $\Delta R^{2}=0,133$ & \multicolumn{3}{|c|}{$\mathrm{F}=49,438$} & \multicolumn{2}{|l|}{$p=0,000$} \\
\hline $\begin{array}{l}\text { Inertia } \\
\text { Alternative Attraction }\end{array}$ & & $-0,035$ & 0,038 & $-0,049$ & $-0,940$ & 0,348 \\
\hline $\mathrm{R}^{2}=0,138$ & $\Delta R^{2}=0,132$ & \multicolumn{3}{|c|}{$\mathrm{F}=25,152$} & \multicolumn{2}{|l|}{$p=0,000$} \\
\hline $\begin{array}{l}\text { Inertia } \\
\text { Alternative Attraction } \\
\text { Inertia*Alternative Attraction }\end{array}$ & & 0,164 & 0,063 & 0,139 & 2,586 & 0,010 \\
\hline$R^{2}=0,156$ & $\Delta R^{2}=0,148$ & \multicolumn{3}{|c|}{$F=19,299$} & \multicolumn{2}{|l|}{$p=0,000$} \\
\hline
\end{tabular}

In light of the table presented above, while it is evident that consumer inertia has an effect on loyalty, it is determined that the alternative attraction variable does not have an effect on loyalty. In determining the moderator effect, however, the consumer inertia $x$ alternative attraction variable was observed to have an effect of $15.6 \%$. At this point, the moderator effect can be interpreted in the following way: The increase in the moderator variable interaction and the corrected $\mathrm{R}^{2}$ value is proof of the moderating role of alternative attraction. A $2.1 \%$ increase has been observed, and the model is significant in terms of the ANOVA values. The $\mathrm{H} 3$ hypothesis has been accepted in accordance with this result.

Another heading taken into consideration within the study was whether the Positive Word-of-Mouth variable had a moderating effect in the relationship between consumer satisfaction and loyalty. The moderating effect of positive wordof-mouth is presented in the table below.

Table 8: The Moderator Effect of Positive Word-Of-Mouth

\begin{tabular}{|c|c|c|c|c|c|}
\hline Model & B & $\begin{array}{l}\text { Std. } \\
\text { Error }\end{array}$ & B & $\mathbf{t}$ & Sig. \\
\hline Satisfaction & 0,515 & 0,041 & 0,582 & 12,722 & 0,000 \\
\hline$\Delta R^{2}=0,403$ & \multicolumn{3}{|c|}{$F=161,841$} & \multicolumn{2}{|c|}{$=0,000$} \\
\hline $\begin{array}{l}\text { Satisfaction } \\
\text { Positive Word of Mouth }\end{array}$ & 0,278 & 0,048 & 0,285 & 5,840 & 0,000 \\
\hline$R^{2}=0,403$ & \multicolumn{3}{|c|}{$F=106,452$} & \multicolumn{2}{|c|}{$=0,000$} \\
\hline $\begin{array}{l}\text { Satisfaction } \\
\text { Positive Word of Mouth } \\
\text { Satisfaction*Positive Word of Mouth }\end{array}$ & 0,054 & 0,054 & 0,245 & 0,989 & 0,323 \\
\hline $\mathrm{R}^{2}=0,405 \quad \Delta \mathrm{R}^{2}=0,399$ & \multicolumn{3}{|c|}{$F=71,289$} & \multicolumn{2}{|c|}{$p=0,000$} \\
\hline
\end{tabular}

When analysis results are examined, it is evident that consumer satisfaction has an effect on loyalty. Aside from this, the positive word-of-mouth variable, along with consumer satisfaction, also has an effect on loyalty. The customer satisfaction*the positive word-of-mouth variable which will be considered for the purpose of determining the moderating effect has no effect. At this point, the moderator effect can be interpreted in the following way: While consumer satisfaction and positive word-of-mouth are effective on consumer loyalty; consumer satisfaction and positive word-ofmouth which is a a moderator variable interaction term, has no effect on loyalty for this reason, positive word-of-mouth has no moderating role. The $\mathrm{H} 4$ hypothesis has been rejected. 


\section{CONCLUSION}

In this study which was carried out to determine the effect of the required qualifications of an online shopping website on consumer inertia and customer satisfaction, the effect of the website's required qualifications on consumer inertia, customer satisfaction and loyalty were examined. Lastly, the attractiveness of alternatives in the relationship between consumer inertia and consumer loyalty, and the moderator role of the positive word-of-mouth variable in the relationship between customer satisfaction and consumer loyalty were studied, and the results below were obtained. The majority of respondents are $18-28$ years of age (68.4\%), have university level education (67.2\%), an income of 1000 TL or less (37.3), are generally composed of women (49.9\%), students (34.5) and single people (69.6\%). It was determined that respondents generally shop from hepsiburada.com (53.0\%), n11 (51.1\%), and Gittigidiyor (50.6\%). Following the definitive statistics, a multiple regression analysis was applied. In this respect, the effect of required qualifications a website on consumer inertia was first examined. As a result of the analysis, it was observed that the dimensions of adaptation, ease and engagement were effective on consumer inertia. In other words, adaptation means the extent to which a recognizes its customers and implement customer-oriented adaptations, and transaction ease is when customers are able to access the information they need with ease, and last of all, engagement is the general image that is reflected onto the customer. These results are supported by the studies available in literature; adaptation, ease and engagement dimensions are features which consumers with a high level of inertia are looking for in a website. In this sense, to ensure businesses can keep consumers in their current shopping websites or to prevent them from steering towards other shopping sites, factors which may cause complications must be eliminated. Also, by ensuring ease, the transaction process will also be simplified. This way, the consumer will be able to complete his or her shopping tirelessly and without wasting time. As the short-term relationship between the two sides advances toward a long-term relationship, consumers will continue to shop from the same online shopping website. In other words, firms that have developed a positive image will be the constant choice of consumers.

According to the analysis results which examine the effect of website's required qualifications on customer satisfaction; while the dimensions of adaptation, interaction, ease and engagement are effective on customer satisfaction, the dimension of assortment is not. In line with this result, it is possible to argue that customer satisfaction in online shopping depends on the website's ability to adapt content, to offer the chance for engagement in existing content, to respond to customer concerns and problems, to be user-friendly by shortening the process and to present an image in this sense. In this regard, it is necessary for them to create a platform in which shoppers can easily find what they are looking for in order to ensure customer satisfaction or exceed expectations. In addition to this, firms can receive feedback from customers thanks to an interactive environment which is one of the greatest opportunities technology offers. This way, firms are able to find out the needs of consumers with ease, and meet their expectations accordingly. The ability of a firm to solve the problems faced by consumers and for them to respond to complaints create a feeling of satisfaction in individuals. Along with this, when consumers are able to complete their shopping process with the least effort and cost, they feel much better. Also, strengthening the ties, or, ensuring engagement, means individuals' needs are met more successfully. According to another result of the analysis, consumer inertia and customer satisfaction are effective on loyalty. Determining the factors which affect loyalty is especially important for firms. When their expectations are met by the firms they do online shopping from, customers show loyalty. Another variable which effects loyalty consumer inertia is. In this context, consumers who refrain from shopping from competing firms because they do not wish to spend the time and money will continue to shop from their current providers. That is to say, by continuing their relationship with the firm they are used to or trust, they avoid uncertainty and risks, and will prefer the firm they have always been shopping from. As a result of the shopping done, the consumer becomes acquainted with the firm and will impulsively choose to shop from the website they have previously experienced.

The moderating effect of alternative attraction that was identified between inertia and loyalty may be interpreted as follows: an individual's inertia will increase his or her desire, or, in other words, his or her loyalty, in terms of continuing to shop from the current site. However, when competing alternatives are perceived positively by a customer, his or her loyalty will be affected negatively. No matter how much loyalty a consumer may feel toward the website from which they constantly shop from in order to avoid extra costs, when competitors' offers are more attractive, the relationship between their loyalty and inertia may weaken. On the other hand, there is no moderating effect of positive word-of-mouth in the relationship between satisfaction and loyalty. This situation can be explained by stating that the comments of people who are in the social circle of a consumer have an effect on loyalty. That is, a satisfied consumer acts in line with his or her own decisions and continues to purchase.

In light of these results, the following suggestions have been developed.

Consumers today generally wish to complete their shopping by spending less time and avoid extra costs. In an online environment, which is a competitive one, firms are increasing the required qualifications of their own websites thanks to technological tools and increasing their efforts to become a shopping site that is the constant choice of individuals. To prevent consumers who are driven by their habits from leaving a website, the website needs to first be adapted according 
to the consumer. To that end, the firm must show an effort to find out the needs of the consumer. With this aim, necessary adjustments can be made with a questionnaire applied at the end of a transaction. For relationships to be long-term, ensuring engagement is also important. In this context, expert designers should be employed to improve a website's attractiveness, and the effects of the colors, logo and content on consumers must be examined.

In terms of inertia, adaptation, ease and comfort must be ensured to transform a consumer's purchasing experience into a habit. By eliminating the perception of risk, the firm must be able to easily accept different product offers. Regarding satisfaction, it can be noted that adaptation, interaction, commitment, transaction ease and engagement are related to loyalty. Firms must make the necessary effort and carry out the necessary actions in order to ensure this. Businesses must not think that consumers with a high level of inerti will not be lost and their loyalty will be constant. This is due to the fact that the high level of competition in the market and the appealing offers presented by competitors may attract this consumer group.

\section{Acknowledgement}

This research presented full text at the "14th International Strategic Management Conference the date of 12-14 July 2018"

\section{REFERENCES}

Anderson, R. E, Srinivasan, S. S. (2003). E-satisfaction and e-loyalty: a contingency framework. Psychology \& Marketing, 20(2), 123-138.

Anderson, R. E., Swaminathan, S. (2011). Customer satisfaction and loyalty in e-markets: a PLS path modeling approach. Journal of Marketing Theory and Practice, 19(2), 221-234.

Baron, R. M., Kenny, D. A. (1986). The moderator-mediator variable distinction in social psychological research: conceptual, strategic, and statistical considerations. Journal of personality and social psychology, 51(6), 1173-1182.

Bayraktar, E., Tatoglu, E., Turkyilmaz, A., Delen, D., Zaim, S. (2012). Measuring the efficiency of customer satisfaction and loyalty for mobile phone brands with DEA. Expert Systems with Applications, 39(1), 99-106.

Bozzo, C. (2002). Understanding inertia in an industrial context. Journal of Customer Behaviour, 1(3), 1-20.

Brodie, R. J., Ilic, A., Juric, B., Hollebeek, L. (2013). Consumer engagement in a virtual brand community: an exploratory analysis. Journal of Business Research, 66(1), 105-114.

Cantallops, A. S., Salvi, F. (2014). New consumer behavior: a review of research on eWOM and hotels. International Journal of Hospitality Management, 36, 41-51.

Casalo, L. V., Flavián, C., Guinalíu, M. (2007). The influence of satisfaction, perceived reputation and trust on a consumer's commitment to a website. Journal of Marketing Communications, 13(1), 1-17.

Chen, Q., Clifford, S. J., Wells, W. D. (2002). Attitude toward the site II: new information. Journal of Advertising Research, 42(2), 33-45.

Cheng, C. C., Chiu, S. I., Hu, H. Y., Chang, Y. Y. (2011). A study on exploring the relationship between customer satisfaction and loyalty in the fast food industry: With relationship inertia as a mediator. African Journal of Business Management, 5(13), 5118-5129.

Christodoulides, G., Michaelidou, N. (2010). Shopping motives as antecedents of e-satisfaction and e-loyalty. Journal of Marketing Management, 27(1-2), 181-197.

Colgate, M., Lang, B. (2001). Switching barriers in consumer markets: an investigation of the financial services industry. Journal of consumer marketing, 18(4), 332-347.

Cristobal, E., Flavián, C., Guinaliu, M. (2007). Perceived e-service quality (PeSQ) Measurement validation and effects on consumer satisfaction and web site loyalty. Managing service quality: An international journal, 17(3), 317-340.

Çankaya, İ., Demirtaş, Z. (2010). Öğretmen adaylarının görüşlerine göre üniversite iklimi ve atalet arasındaki ilişki. Pamukkale Üniversitesi Eğitim Fakültesi Dergisi, 28(28), 1-9.

Dann, S., Dann, S. (2011). E-marketing: theory and application. Palgrave macmillan.

Devaraj, S., Fan, M., Kohli, R. (2002). Antecedents of B2C channel satisfaction and preference: validating e-commerce metrics. Information systems research, 13(3), 316-333.

Dutot, V. (2013). A new strategy for customer engagement: how do French firms use social CRM?. International Business Research, 6(9), 54-67.

File, K. M., Prince, R. A. (1992). Positive word-of-mouth: customer satisfaction and buyer behaviour. International Journal of Bank Marketing, 10(1), 25-29. 
Harrison-Walker, L. J. (2002). If you build it, will they come? Barriers to international e-marketing. Journal of Marketing Theory and practice, 10(2), 12-21.

Hoch, S. J., Bradlow, E. T., Wansink, B. (1999). The variety of an assortment. Marketing Science, 18(4), 527-546.

Huang, M. H., Yu, S. (1999). Are consumers inherently or situationally brand loyal?-a set intercorrelation account for conscious brand loyalty and nonconscious inertia. Psychology \& Marketing, 16(6),523-544.

Jones, M. A., Mothersbaugh, D. L., Beatty, S. E. (2000). Switching barriers and repurchase intentions in services. Journal of retailing, 76(2), 259-274.

Kassim, N., Asiah Abdullah, N. (2010). The effect of perceived service quality dimensions on customer satisfaction, trust, and loyalty in ecommerce settings: a cross cultural analysis. Asia Pacific Journal of Marketing and Logistics, 22(3), 351-371.

Keaveney, S. M. (1995). Customer switching behavior in service industries: an exploratory study, Journal of Marketing, Vol. 59 No. 2, 71-82.

Kim, J. S., Kaye, J., Wright, L. K. (2001). Moderating and mediating effects in causal models. Issues in Mental Health Nursing, 63-75.

Kim, C., Zhao, W., Yang, K. H. (2008). An empirical study on the integrated framework of e-CRM in online shopping: evaluating the relationships among perceived value, satisfaction, and trust based on customers' perspectives. Journal of Electronic Commerce in Organizations, 6(3), 1-19.

Kim, J., Jin, B., Swinney, J. L. (2009). The role of etail quality, e-satisfaction and e-trust in online loyalty development process. Journal of retailing and Consumer services, 16(4), 239-247.

Koo, D. M., Kim, J. J., Lee, S. H. (2008). Personal values as underlying motives of shopping online. Asia Pacific Journal of Marketing and Logistics, 20(2), 156-173.

Kuo, Y. F., Hu, T. L., Yang, S. C. (2013). Effects of inertia and satisfaction in female online shoppers on repeat-purchase intention: the moderating roles of word-of-mouth and alternative attraction. Managing Service Quality: An International Journal, 23(3), 168-187.

Lee, G. G., Lin, H. F. (2005). Customer perceptions of e-service quality in online shopping. International Journal of Retail \& Distribution Management, 33(2), 161-176.

Lee, R., Neale, L. (2012). Interactions and consequences of inertia and switching costs. Journal of services marketing, 26(5), 365-374.

Leisen, B., Prosser, E. (2004). Customers' perception of expensiveness and its impact on loyalty behaviors. Services Marketing Quarterly, 25(3), 35-52.

Lien, C. H., Cao, Y. (2014). Examining WeChat users' motivations, trust, attitudes, and positive word-of-mouth: evidence from China. Computers in Human Behavior, 41, 104-111.

Liu, T. C., Wu, L. W., Hung, C. T. (2007). The effects of inertia and switching barriers on satisfaction-retention relationship: a case of financial service industries, Journal of Management, Vol. 24 No. 6, 671-687.

Lindley, P., Walker, S. N. (1993). Theoretical and methodological differentiation of moderation and mediation. Nursing Research, 42, 276279.

Lucia-Palacios, L., Pérez-López, R., Polo-Redondo, Y. (2016). Enemies of cloud services usage: inertia and switching costs. Service Business, 10(2), 447-467.

Maxham III, J. G., Netemeyer, R. G. (2002). A longitudinal study of complaining customers' evaluations of multiple service failures and recovery efforts. Journal of marketing, 66(4), 57-71.

Masood, O., Javaria, K. (2016). Inertia and online trust leading factors affecting consumer repeat-purchase intention in e-commerce (moderating role of alternative attraction). The Journal of Internet Banking and Commerce, 76(3), 309-322.

Moore, M., Carpenter, J. (2006). The effect of price as a marketplace cue on retail patronage. Journal of Product \& Brand Management, 15(4), 265-271.

Mousaveian, S. A., Ebrahimpour, H., Hasanzadeh, M., Mousaveian, N. (2016). The role of e-value, e-trust, e-commitment and e-satisfaction on customers e-loyalty with emphasis on internet banking. International Journal of Management Research and Reviews, 6(5), 741-747.

Noble, S. M., Griffith, D. A., Adjei, M. T. (2006). Drivers of local merchant loyalty: understanding the influence of gender and shopping motives. Journal of Retailing, 82(3), 177-188.

Oliver, R. L. (1999). Whence consumer loyalty?. Journal of Marketing, Vol. 63 No. 4, 33-44

Park, M., Park, J. (2009). Exploring the influences of perceived interactivity on consumers'e-shopping effectiveness. Journal of customer behaviour, 8(4), 361-379.

Pechtl, H. (2003). Adoption of online shopping by German grocery shoppers. The International Review of Retail, Distribution and Consumer Research, 13(2), 145-159. 
Pitta, D., Franzak, F., Fowler, D. (2006). A strategic approach to building online customer loyalty: integrating customer profitability tiers. Journal of consumer marketing, 23(7), 421-429.

Raney, A. A., L. M. Arpan, K. Padhupati D. A. Brill. (2003). At the movies, on the web: an investigation of the effects of entertaining and interactive web content on site and brand evaluations. Journal of Interactive Marketing, 17(4), 38-53.

Razak, M. Z. B. A., Ilias, A., Rahman, R. A. (2009). Differentiation strategies of internet retailing (unique, value and return): A focused web evaluation into airline service provider. International Business Research, 2(2), 40-47.

Richard, M. O., Chandra, R. (2005). A model of consumer web navigational behavior: conceptual development and application. Journal of business Research, 58(8), 1019-1029.

Roy Dholakia, R., Zhao, M. (2009). Retail web site interactivity: how does it influence customer satisfaction and behavioral intentions?. International Journal of Retail \& Distribution Management, 37(10), 821-838.

Taylor, M. J., England, D. (2006). Internet marketing: web site navigational design issues. Marketing Intelligence \& Planning, $24(1), 77-85$.

Tsai, H. T., Huang, H. C. (2007), Determinants of e-repeat-purchase intentions: an integrative model of quadruple retention drivers, Information and Management, Vol. 44 No. 3, 231-239.

Sashi, C. M. (2012). Customer engagement, buyer-seller relationships, and social media. Management decision, 50(2), $253-272$.

Sheth, J. N., Sharma, A. (2005). International e-marketing: opportunities and issues. International Marketing Review, 22(6), 611-622.

Shih, D. H., Chiang, H. S. (2004). E-mail viruses: how organizations can protect their e-mails. Online Information Review, 28(5), 356-366.

Solomon, M. R. (1994). Consumer behavior: buying, having and being, 2nd ed. Paramount Publishing, Boston, MA.

Solomon, M. R. (2007). Consumer behavior: buying, having, and being, 7th ed. Paramount Publishing, Boston, MA

Szymanski, D. M., Hise, R. T. (2000). E-satisfaction: an initial examination. Journal of retailing, 76(3), 309-322.

Wangenheim, F. (2003). Situational characteristics as moderators of the satisfaction-loyalty link: an investigation in a business-to-business context. Journal of Consumer Satisfaction, Dissatisfaction and Complaining Behavior, 16, 1-27.

Westbrook, R. A. (1987). Product/consumption-based affective responses and postpurchase processes. Journal of Marketing Research, 24(3), 258-270.

Wu, L. W. (2011). Inertia: spurious loyalty or action loyalty?. Asia Pacific Management Review, 16(1), 31-50.

Yanamandram, V., White, L. (2006). Switching barriers in business-to-business services: a qualitative study. International Journal of Service Industry Management, 17(2), 158-192.

Yanamandram, V., White, L. (2010). Are inertia and calculative commitment distinct constructs? An empirical study in the financial services sector. International Journal of Bank Marketing, 28(7), 569-584.

Yang, Z., Peterson, R. T. (2004). Customer perceived value, satisfaction, and loyalty: the role of switching costs. Psychology \& Marketing, 21(10), 799-822.

Zhang, Y., Fang, Y., Wei, K. K., Ramsey, E., McCole, P., Chen, H. (2011). Repurchase intention in B2C e-commerce-a relationship quality perspective. Information and Management, 48(6), 192-200.

Zhao, L., Tian, P., Li, X. (2012). Dynamic pricing in the presence of consumer inertia. Omega, 40(2), 137-148.

Zhou, Y., Amin, M. (2014). Factors affecting online community commitment in China: a conceptual framework. Journal of Technology Management in China, 9(1), 24-36. 